Regeda-Furdychko M. M. The role of lipid peroxidation and antioxidant protection in skin in the development of experimental contact dermatitis. Journal of Education, Health and Sport. 2020;10(12):56-64. eISSN 2391-8306. DOI http://dx.doi.org/10.12775/JEHS.2020.10.12.006

https://apcz.umk.pl/czasopisma/index.php/JEHS/article/view/JEHS.2020.10.12.006

https://zenodo.org/record/4317706

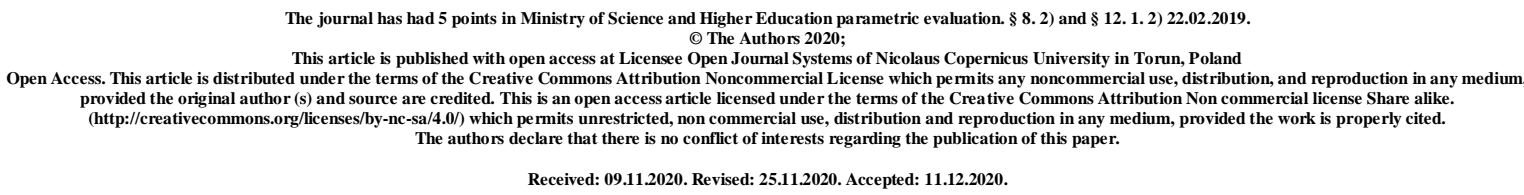

UDK: 616.5-022.913-092:612.79.014.11].019

\title{
THE ROLE OF LIPID PEROXIDATION AND ANTIOXIDANT PROTECTION IN SKIN IN THE DEVELOPMENT OF EXPERIMENTAL CONTACT DERMATITIS
}

\section{M. Regeda-Furdychko}

\section{Lviv Medical Institute}

\section{Abstract}

The purpose of work to study the conditions of prooxidant and antioxidant system in the skin of guinea pigs in different periods of contact dermatitis formation.

Materials and methods. Researches were conducted on guinea pigs, divided into five groups: I - control, II $-4^{\text {th }}$ day of expirement, III $-8^{\text {th }}$ day of contact dermatitis development, IV $-10^{\text {th }}$ day and $\mathrm{V}-18^{\text {th }}$ day of model process. Early period included groups of animals on the $4^{\text {th }}$ and $8^{\text {th }}$ days of experiment. The late one - guinea pigs on the $10^{\text {th }}$ and $18^{\text {th }}$ days of contact dermatitis. Experimental contact dermatitis was simulated by method of Volkovoj V. A. (2010). Condition of free radical lipid oxidization in the skin was determined on maintenance content of malonic dialdehyde by method of Corobeynikov E. G. (1989) and diene conjugates by method of Gavrylov V. G., Myshkorudna M. I. (1989). The degree of activity of antioxidant defence was estimated on maintenance enzymes - superoxidedismutase by method of R. Fried (1975), catalase by the method of B. Holmes, C. Masters (1970), glutationperoxidase method of Arkhipova O. G. (1988) and glutationreductase method of Moina V. M. (1986). 
Results and discussion. Gradual increasing of lipid peroxydations products - malonic dialdehyde, diene conjugate had been determined on the $4^{\text {th }}, 8^{\text {th }}, 10^{\text {th }}$ and $18^{\text {th }}$ days of experimental contact dermatitis development in this research. Primary increasing of the indices of superoxidedismutase, glutationreductase, glutationperoxidase and catalase has been investigated in the skin on the $4^{\text {th }}$ day with the following decreasing of these enzymes from the $8^{\text {th }}$ day of experiment. It testified about imbalance in antioxidant and prooxydant systems, especially on the $10^{\text {th }}$ and $18^{\text {th }}$ days of the study, which exacerbates the inflammatory process in the skin and also triggers a cascade of other mechanisms of damage.

Key words: contact dermatitis; malonic dialdehyde; diene conjugate; superoxidedismutase; catalase; glutationperoxidase; glutationreductase.

\section{РОЛЬ ПРОЦЕСІВ ПЕРЕКИСНОГО ОКИСНЕННЯ ЛІПІДІВ ТА АНТИОКСИДАНТНОГО ЗАХИСТУ В ШКІРІ В ДИНАМІЦ РОЗВИТКУ ЕКСПЕРИМЕНТАЛЬНОГО КОНТАКТНОГО ДЕРМАТИТУ.}

\section{М. М. Регеда-Фурдичко}

\section{Львівський медичний інститут}

Мета нашого дослідження - з'ясування стану прооксидантної i антиоксидантної системи в шкірі морських свинок у різні періоди формування контактного дерматиту.

Матеріал і методи дослідження. Експериментальні дослідження проводились на морській свинках, поділених на 5 груп по 9 тварин у кожній. До I групи (контроль) відносили інтактні морські свинки, до II- тварини з експериментальним контактним дерматитом (4-а доба), до III - морські свинки на 8-у добу модельного процесу, до IV тварини на 10-у добу та V - мурчаки на 18-у добу контактного дерматиту. 3 метою детального аналізу та інтерпретації показників прооксидантної та антиоксидантної систем у різні доби експерименту виділяли умовно два періоди розвитку експериментального контактного дерматиту: ранній і пізній. Ранній період включав групу тварин на 4-у та 8-у доби експерименту. Пізній - морські свинки на 10-у та 18-у доби контактного дерматиту.

Експериментальна модель контактного дерматиту відтворювалась на морських свинках за методом Волковой В.А. (2010). Стан вільнорадикального окиснення ліпідів 
у шкірі визначали за вмістом дієнових кон'югатів за методом В.Г. Гаврилова, М.І. Мишкорудної (1989), і малонового діальдегіду за методом Е.Н. Коробейникова (1989). Ступінь активності антиоксидантної системи оцінювали за вмістом ферментів супероксиддисмутази за методом R. Fried (1975), каталази за методом R. Holmes, C. Masters (1970), глутатіонпероксидази - за методом Архиповой О.Г. (1988) та глутатіонредуктази-за методом В. М. Моїна (1986).

Результати дослідження та їх обговорення. У роботі встановлено поступове зростання продуктів вільнорадикального окиснення - дієнових кон'югатів та малонового діальдегіду на усі доби формування експериментального контактного дерматиту. Встановлено початкове підвищення активності супероксиддисмутази, каталази, глутатіонредуктази та глутатіонпероксидази в шкірі на 4-у добу, з наступним зниженням цих ферментів з 8-ї добу експерименту, що свідчило про порушення рівноваги між прооксидантною та антиоксидантною системами, особливо на 10-у і 18-у доби дослідження, що посилює запальний процес в шкірі, а також запускає каскад інших механізмів пошкодження.

Ключові слова: контактний дерматит; малоновий діальдегід; дієнові кон'югати; супероксиддисмутаза; каталаза; глутатіонпероксидаза; глутатіонредуктаза.

\section{РОЛЬ ПРОЦЕССОВ ПЕРЕКИСНОГО ОКИСЛЕНИЯ ЛИПИДОВ И АНТИОКСИДАНТНОЙ ЗАЩИТЫ В КОЖЕ В ДИНАМИКЕ РАЗВИТИЯ ЭКСПЕРИМЕНТАЛЬНОГО КОНТАКТНОГО ДЕРМАТИТА}

\section{М. М. Регеда-Фурдичко}

\section{Львовский медицинский институт}

Цель работы - изучить состояние прооксидантной и антиоксидантной систем в коже морских свинок в разные периоды формирования экспериментального контактного дерматита.

Материалы и методы. Исследования проводили на морских свинках, разделенных на пять груп: I группа - контрольная, II- 4-е сутки эксперимента, III - 8-е сутки развития контактного дерматита, IV - 10-е сутки и V - 18-е сутки модельного 
процесса. Ранний период включал группу животных на 4-е и 8-е сутки эксперимента. Поздний - морские свинки на 10-е и 18-е сутки контактного дерматита. Экспериментальная модель контактного дерматита воспроизводилась методом Волкова В.А.(2010). Состояние свободнорадикального окисления липидов в коже определяли по содержанию диеновых коньюгатов методом В.Г. Гаврилова, М.И. Мышкорудной (1989), и малонового диальдегида методом Е.Н.Коробейникова (1989). Степень активности антиоксидантной защиты оценивали по содержанию ферментов супероксиддисмутазы методом R. Fried (1975), каталазы методом B. Holmes, C. Masters (1970), глутатионредуктазы методом Моина В.М. (1986) и глутатионпероксидазы методом Архиповой О.Г. (1988).

Результаты и обсуждение. В работе установлено постепенный рост продуктов свободнорадикального окисления - диеновых конъюгатов и малонового диальдегида на все этапы формирования экспериментального контактного дерматита. Установлено первоначальное повышение активности супероксиддисмутазы, каталазы, глутатионредуктазы и глутатионпероксидазы в коже на 4-е сутки, с последующим снижением этих ферментов с 8-ых суток эксперимента, что свидетельствовало о нарушении равновесия между прооксидантной и антиоксидантной системами, особенно на 10-е и 18-е сутки исследования, что усиливает воспалительный процесс в коже, а также запускает каскад других механизмов повреждения.

Ключевые слова: контактный дерматит; малоновый диальдегид; диеновые коньюгаты; супероксиддисмутаза; каталаза; глутатионпероксидаза; глутатионредуктаза.

Introduction. In today's world, it is difficult to overestimate the impact of the environment and occupational hazards on human health. Environmental pollution, especially in industrialized countries, constant contact both at home and in the workplace with chemicals (building materials, metals, household chemicals, cosmetics), the use of various drugs for local treatment and disinfection have led to an increase in the prevalence of contact dermatitis (CD) [10]. The incidence of the disease reaches $15-20 \%$ among the adult population $[9,16]$.

The study of modern aspects of the pathogenesis of any disease is impossible without studying the mechanisms of destabilization of biological membranes, which form the basis of many pathological reactions of the human body, including skin diseases [4, 7, 12, 15]. Lipid peroxidation is the oxidative degradation of lipids, which occurs under the action of free radicals and is one of the main causes of damage to cell membranes and subsequent cell death 
due to exposure to reactive oxygen species. This process regulates the lipid composition of biomembranes and membrane-associated enzymes, participates in the synthesis of leukotrienes, prostaglandins, metabolism of catecholamines and steroid hormones, affects the permeability of membranes and the transport of substances through them [7, 8, 11]. It is known that oxidative stress is an integral part of the pathogenesis of various types of dermatitis [12], so the aim of our research to study the conditions of prooxidant and antioxidant system in the skin of guinea pigs in different periods of contact dermatitis formation.

Material and research methods. Experimental studies were performed on 51 guinea pigs (males) weighing 180 - $220 \mathrm{~g}$, divided into 5 groups of 9 animals each, except the first (15 animals). Group I (control) included intact guinea pigs, to group II, III, IV and V animals with experimental $\mathrm{CD}$ on the $4^{\text {th }}, 8^{\text {th }}, 10^{\text {th }}$ and $18^{\text {th }}$ days. For the purpose of detailed analysis and interpretation of indicators of prooxidant and antioxidant systems in different days of the experiment, two periods of the development of CD were distinguished: early and late. The chosen days of experimental $\mathrm{CD}$ were due to the classical stages of the inflammatory process. Early period included groups of animals on the $4^{\text {th }}$ and $8^{\text {th }}$ days of experiment. The late one - guinea pigs on the $10^{\text {th }}$ and $18^{\text {th }}$ days of contact dermatitis.

Experimental CD was reproduced on guinea pigs by the method of VA Volkova (2010) [1]. All experimental animals were kept in standard conditions vivarium of Lviv National Medical University Danylo Halytsky. Euthanasia of animals was performed by decapitation under ether anesthesia in compliance with the European Convention for the Protection of Vertebrate Animals Used for Experimental and Other Scientific Purposes (Strasbourg, 1985). Condition of free radical lipid oxidation in the skin was determined by the content of diene conjugates (DC) by the method of VG Gavrylov, MI Myshkorudna (1989) [2], and malonic dialdehyde (MDA) by the method of EG Korobeynikov (1989) [3].

The degree of antioxidant system activity was estimated by the content of enzymes superoxide dismutase (SOD) by the method of R. Fried (1975) [13], catalase (CT) by the method of R. Holmes, C. Masters (1970) [14], glutathione peroxidase (GPO) - by the method of OG Arkhipova (1988) [6] and glutathione reductase (GR) - by the method of VM Moin (1986) [5]. Statistical processing of the obtained data was carried out according to the Student's method

Research results and their discussion. The results of biochemical studies indicate that animals with the development of experimental contact dermatitis have characteristic signs of oxidative stress. This is manifested by the consistent accumulation of lipoperoxidation 
products in the skin during all periods of contact dermatitis. In particular, the content of DC increased by $30.8 \%, 59.2 \%, 67.9 \%$ and $82.7 \%(\mathrm{p} \leq 0.05)$, respectively, on the $4^{\text {th }}, 8^{\text {th }}, 10^{\text {th }}$ and $18^{\text {th }}$ days in comparison with intact animals that testifies to stimulation of processes of free radical oxidation (fig. 1).

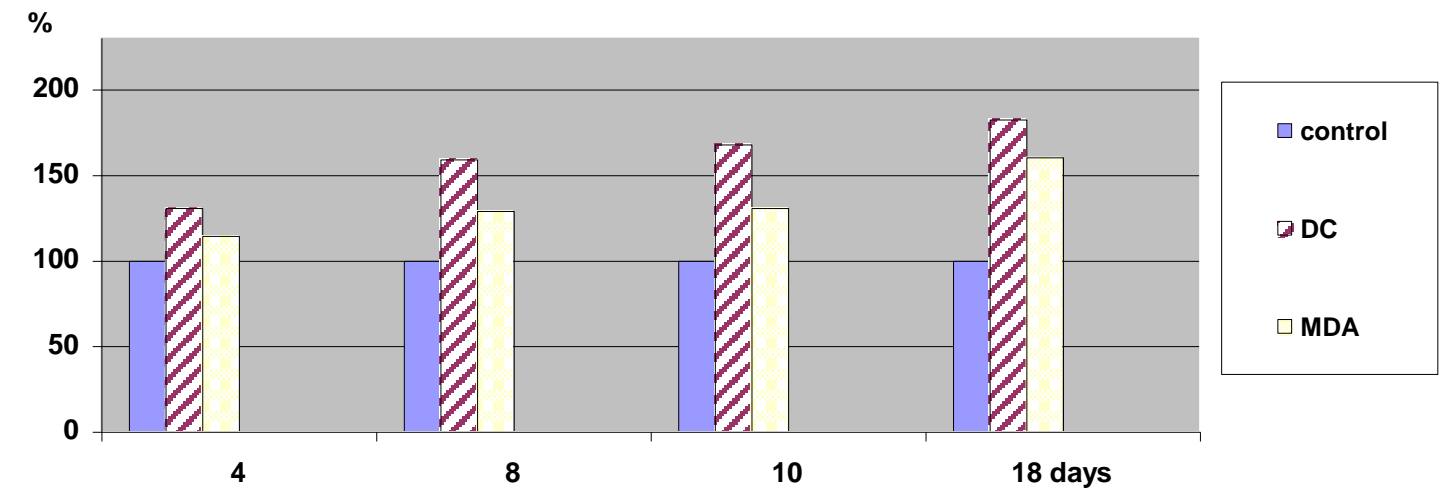

Fig. 1. The content of lipid peroxidation products in guinea pig skin in the dynamics of $\mathrm{CD}$ formation (\% of control)

Determination of the content of MDA in the skin have established its gradual increasing by $14.6 \%(\mathrm{p} \leq 0.05)$ on the $4^{\text {th }}$ day and by $29.2 \%(\mathrm{p} \leq 0.05)$ on the $8^{\text {th }}$ day of $C D$, on the $10^{\text {th }}$ and $18^{\text {th }}$ days, respectively, by $30.8 \%$ and $60.5 \%(\mathrm{p} \leq 0.05)$ compared with control values, indicating the stimulation of the prooxidant system and excessive formation of lipid peroxidation products, especially in the late period of this experimental disease model.

Regarding the activity of the antioxidant system enzymes in the skin of animals under the conditions of contact dermatitis formation, their different changes were revealed during all periods of the experiment development. When determining the activity of SOD in the skin, we note a gradual growth of $11.2 \%(\mathrm{p} \leq 0.05)$ on the $4^{\text {th }}$ and $21.9 \%(\mathrm{p} \leq 0.05)$ on the $8^{\text {th }}$ day of CD in comparison with the first group guinea pigs (fig. 2). Later, on the $10^{\text {th }}$ and $18^{\text {th }}$ days of the experiment, a significant decrease was found by $39.2 \%(\mathrm{p} \leq 0.05)$ and $43.0 \%(\mathrm{p} \leq 0.05)$, respectively, against the indicators of the intact group, which indicates first on stimulation, and then on suppression of the investigated enzyme.

A similar direction of change was found during the study of catalase activity in the skin. Thus, on the $4^{\text {th }}$ and $8^{\text {th }}$ days of CD revealed an increase in its activity by $11.7 \%$ $(\mathrm{p} \leq 0.05)$ and $28.7 \%(\mathrm{p} \leq 0.05)$, respectively, and in the late period of this experimental model of the disease there is a reduction in CT activity by $37.7 \%(\mathrm{p} \leq 0.05)$ and $44.2 \%(\mathrm{p} \leq 0.05)$ on 
the $10^{\text {th }}$ and $18^{\text {th }}$ day compared with the control, which gives reason to say on the suppression of antioxidant protection (fig. 2).

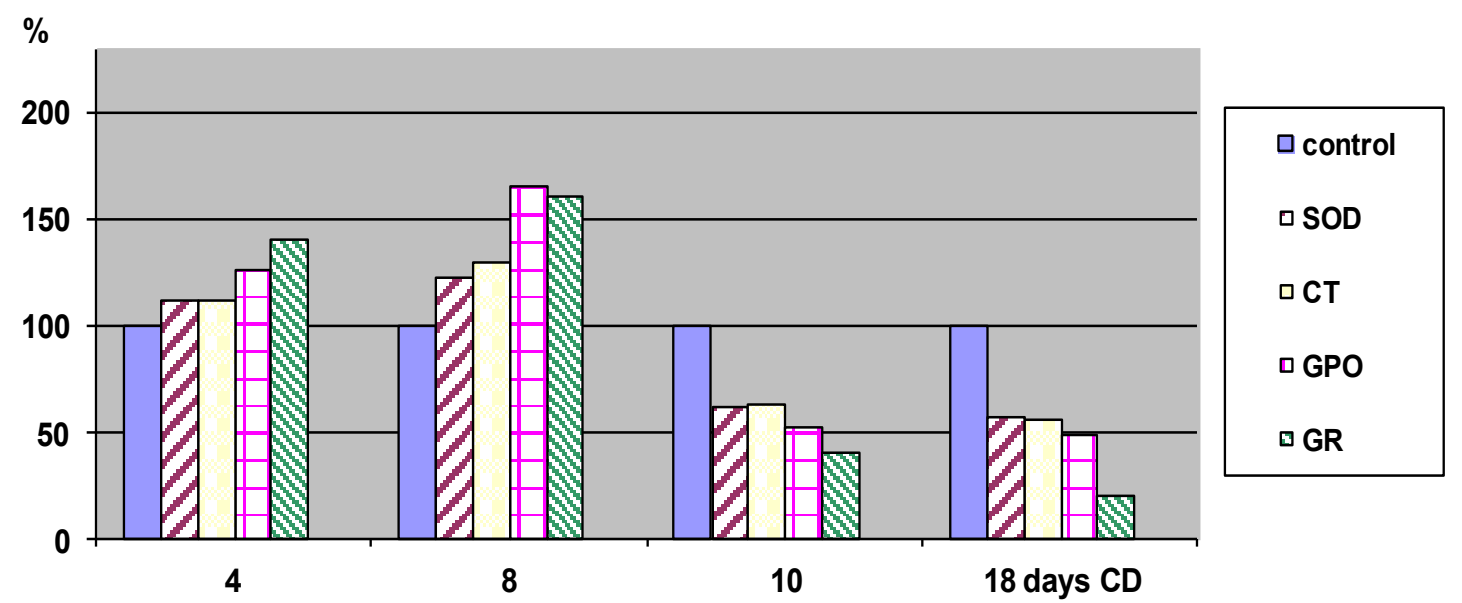

Fig. 2. Activity of antioxidant system enzymes in guinea pig skin in the dynamics of CD formation (\% of control)

Important markers that complement the characteristics of the previous ones are gutathione peroxidase and glutathione reductase. The early period of CD formation was accompanied by an increase in the activity of GPO in the skin by $26.0 \%(\mathrm{p} \leq 0.05)$ and $65.2 \%$ $(\mathrm{p} \leq 0.05)$, and GR by $40.0 \%(\mathrm{p} \leq 0.05)$ and $60.0 \%(\mathrm{p} \leq 0.05)$ against the intact group, respectively, on the $4^{\text {th }}$ and $8^{\text {th }}$ day of the experiment. Opposite changes in the studied parameters in the skin of guinea pigs are recorded in the subsequent days of development of contact dermatitis. The activity of GPO decreased by $47.8 \%(\mathrm{p} \leq 0.05)$ and by $52.1 \%(\mathrm{p} \leq 0.05)$ on the $10^{\text {th }}$ and $18^{\text {th }}$ days, respectively, compared with group I animals. Regarding the activity of GR, an even more significant decrease was recorded by $60.0 \%(\mathrm{p} \leq 0.05)$ on the $10^{\text {th }}$ day and by $80.0 \%$ ( $\mathrm{p} \leq 0.05$ ) on the $18^{\text {th }}$ day of the $\mathrm{CD}$ opposite the control (fig. 2 ).

Conclusions. Summarizing the results of the study, we can say that all periods of experimental contact dermatitis are characterized by dysfunction of the proxidant and antioxidant systems, which is manifested by excessive accumulation of lipid peroxidation products (increasing levels of DC and MDA) and multidirectional changes in antioxidant protection: first there was an increase in the activity of enzymes SOD, CT, GR, GPO as a possible compensatory mechanism, and then their decrease, indicating a violation of cellular homeostasis and the development of oxidative stress, especially on the $10^{\text {th }}$ and $18^{\text {th }}$ day of the 
study, which exacerbates the inflammatory process in the skin, and triggers a cascade of other damage mechanisms.

Prospects for further research. In the future it is planned to study the prooxidant and antioxidant system in the skin of guinea pigs in the dynamics of experimental contact dermatitis in experimental pneumonia.

\section{REFERENCES}

1. Volkova V.A., Kuchynska I.V., Tiupka T.I. Study of the therapeutic efficacy of a new ointment with a lipophilic complex of the Tremulin aspen bark under conditions of nonallergic contact dermatitis in rats. Pharmacology and drug toxicology. 2010;7-12.

2. Gavrilov V.B., Mishkorudnaya M.I. Spectrophotometric determination of lipid hydroperoxides in blood plasma. Laboratornaya diagnostika ishemicheskoy bolezni serdtsa. Kiev, Zdorovye, 1989. 170-171.

3. Korobeynikova E.N. Modifikation of determination of LP products in reaction with thiobarbituric acid. Laboratornoe delo 1989; 7: 8-10.

4. Lytvynec E.A., Goculjak J.V. Lipid peroxidation and antioxidant protection in case of pathology of the urinary system, expediency of using bioflavonoids in complex treatment. Zdorovye mushchyny.2012.1.135-137.

5. Moin V.M. Simple and specific method of determination of activity of glutathion reductase in erythrocytes. Laboratornoe delo 1986; 12: 724-727.

6. Arkhipova O.H. Opredelenie aktivnosti peroksidazy v krovi. Metody issledovaniya v profpatologii. Moscow, Meditsina, 1988. p. 153.

7. Nizhenkovska I.V., Nizhenkovskiy O.I., Vilchinska V.V. et al. Processes of lipoperoxidation and state of $\mathrm{AO}$ systems in myocardium of rats under condition of intoxication of antracylic antibiotics. Suchasni problemy toksykologii 2012; 2: 45-47.

8. Tjashka O.V., Zagorodnja J.M. State of lipid peroxidation and antioxidant system in children of all ages. Perynatologia and pediatria. 2016.2. 101-105.

9. Chudan-Cilo I.I., Corda M.M. Strukturni zminy shkiry pry kontaktnomu nikelevomu dermatyti. Visnyk morphologii. 2017.2. 23. 198-202.

10. Kostner, L., Anzengruber, F., Guillod, C., Recher, M., Schmid-Grendelmeier, P., \& Navarini, A. A. (2017). Allergic contact dermatitis. Immunology and Allergy Clinics, 37 (1), 141-152.

11. Beeckman D., Campbell J., Chimentro D. et al. Proceedings of the Global IAD Expert Panel. Incontinence associated dermatitis: moving prevention forward . Wounds International. 2015. $21 \mathrm{p}$. 
12. Ji, H., \& Li, X. K. Oxidative stress in atopic dermatitis. Oxidative medicine and cellular longevity. 2016.

13. Fried R. Enzymatic and nonenzymatic assay of superoxide ifilli. Biochemie 1975; 57 (5): 657-660.

14. Holmes R., Masters With. Epigenetic interconversions of the multiple forms of mouse liver catalase. FEBS Lett 1970; 11 (1): 45-48.

15. Kubesy, A. A., Salem, N. Y., \& Jaheen, A. H. (2017). Altered blood oxidative stress biomarkers in association with canine pyoderma and allergic contact dermatitis. Comparative Clinical Pathology, 26(3), 643-646.

16. Lim, H. W., Collins, S.A., Jr Resneck, J. S., Bolognia, J.L., Hodge, J.A., Rohrer, T.A., Moyano, J.V. (2017). The burden of skin disease in the United States. Journal of the American Academy of Dermatology, 76, 958-972. 